\title{
Tsunami-induced sediment transport in the abyssal Mediterranean Sea
}

\author{
KIM A. KASTENS* University of California, San Diego, Marine Physical Laboratory of the. Scripps Institution of Oceanography, \\ La Jolla, California 92093 \\ MARIA B. CITA Instituto di Geologia, University of Milan, Milan, Italy
}

\section{ABSTRACT}

An unusual stratigraphic unit (nicknamed "homogenite") fills topographic lows in the complex ridge and trough bathymetry at two survey sites on the Western Mediterranean Ridge and the Calabrian Ridge. On near-bottom $4-\mathrm{kHz}$ seismic-reflection profiles, this unit us an acoustically transparent, near-surface, flat-lying layer, whereas in cores, it is a homogeneous gray marl as much as 7 $m$ thick. Grain size decreases upcore within the unit, implying that it was deposited in a single event controlled by gravitational settling. The stratigraphic position of the homogenite relative to a firmly dated sapropel bed suggests emplacement between 4400 and $3100 \mathrm{yr}$ B.P. The source of the homogenite is inferred to be the nearby basin walls. Farther east, two other sites with similar rugged topography lack homogenite entirely.

A triggering mechanism is required which is capable of initiating massive sediment transport simultaneously in many separate basins at the western two survey sites, but which is not effective at the eastern sites. A large archeologically recorded earthquake of the correct age is considered and rejected because its epicenter is closer to the nonhomogenite-bearing sites than to the sites where this sediment type was observed, and because several other earthquakes of comparable magnitude have since been recorded in the area, whereas the homogenite is unique. The 3,500 yr B.P. collapse of the caldera of the volcano of Santorini caused a huge tsunami which is recorded archeologically and geologically around the eastern Mediterranean. Because of refraction of the tsunami by the bathymetry, and because the caldera collapsed in its southwest corner, a disproportionate amount of tsunami energy was directed toward the western area where homogenite is observed. In contrast, the homogenite-free sites were relatively sheltered. An order-ofmagnitude calculation shows that the near-bottom oscillating currents accompanying the Santorini tsunami were at or above the threshold erosion velocity at the homogenite-bearing sites. In addition, the near-bottom pressure pulse under the tsunami at the homogenite-bearing sites was sufficient to cause liquefaction of sediments. Neither mechanism was adequate to cause sediment transport or slope failure at the homogenite-free sites.

*Present address: Lamont-Doherty Geological Observatory, Palisades, New York 10964.

\section{INTRODUCTION}

During the summer of 1978 , two oceanographic cruises explored areas of the eastern Mediterranean (Fig. 1) characterized by a peculiar hummocky relief that is referred to as "cobblestone topography." First, the Deep Tow Instrument Package of the Marine Physical Laboratory of Scripps Institution of Oceanography (Spiess and Tyce, 1973) was used to obtain bathymetric, side-looking sonar, and 4-kHz seismic-reflection data. After preliminary data reduction, R/V Eastward obtained 40 cores precisely located with respect to the geophysical data by means of the same acoustic transponders used on the first cruise.

The highly irregular topography of basins and domes and ridges and troughs which makes up the "cobblestone" terrain is the setting for a complex system of small-scale sediment erosion, transport, and depositional processes. This paper describes an unusual sediment type that we suggest.was deposited from sediment transport induced by the tsunami which followed the $3500 \mathrm{yr}$ B.P. eruption and collapse of the caldera of Santorini. A description of the sedimentology and acoustic nature of the sediment, its distribution, age, and provenance, will be followed by a detailed discussion of the plausibility of this unorthodox sediment transport triggering mechanism.

\section{NATURE OF' THE SEDIMENT}

\section{Description}

During the near-bottom seismic-reflection survey, a distinct acoustically transparent unit was found occupying the uppermost part of the sediment column in certain areas (Fig. 2). It fills local depressions and shows a flat upper surface and a slightly concave upward contact with the acoustically layered sediment below. In thickness it ranges from barely discernible to $>10 \mathrm{~m} \mathrm{sec}$ two-way travel time $(>7.5 \mathrm{~m})$.

Eleven cores were recovered from six separate basins containing the transparent layer. In each case, the transparent layer correlated with a thick, gray, hemipelagic marl unit. Quartz and clays dominate the terrigenous component of this marl. and the biogenic fraction is predominantly nannofossils. The basal contact is sharp and perhaps erosional. The unit starts with a half-centimetre-thick

Geological Society of America Bulletin, Part I, v. 92, p. 845-857, 10 figs., 1 table, November 1981. 


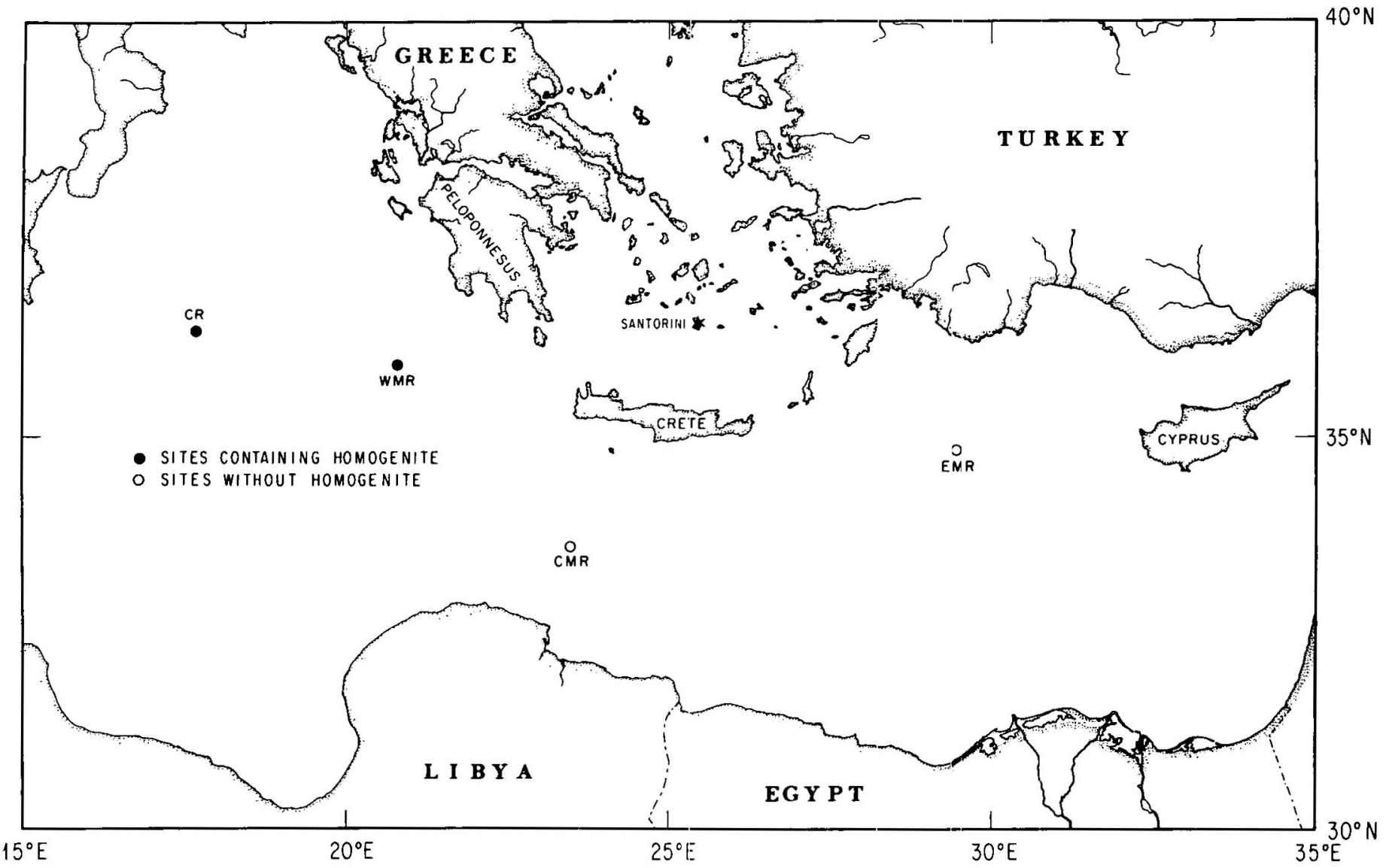

Figure 1. Location map showing the survey area on the Mediterranean Ridge and the Calabrian Ridge. All four sites were surveyed with the Deep Tow and an intensive coring program was conducted at the western two sites. CR is the Calabrian Ridge Site; WMR, CMR, and EMR are western, central, and eastern Mediterranean Ridge sites.

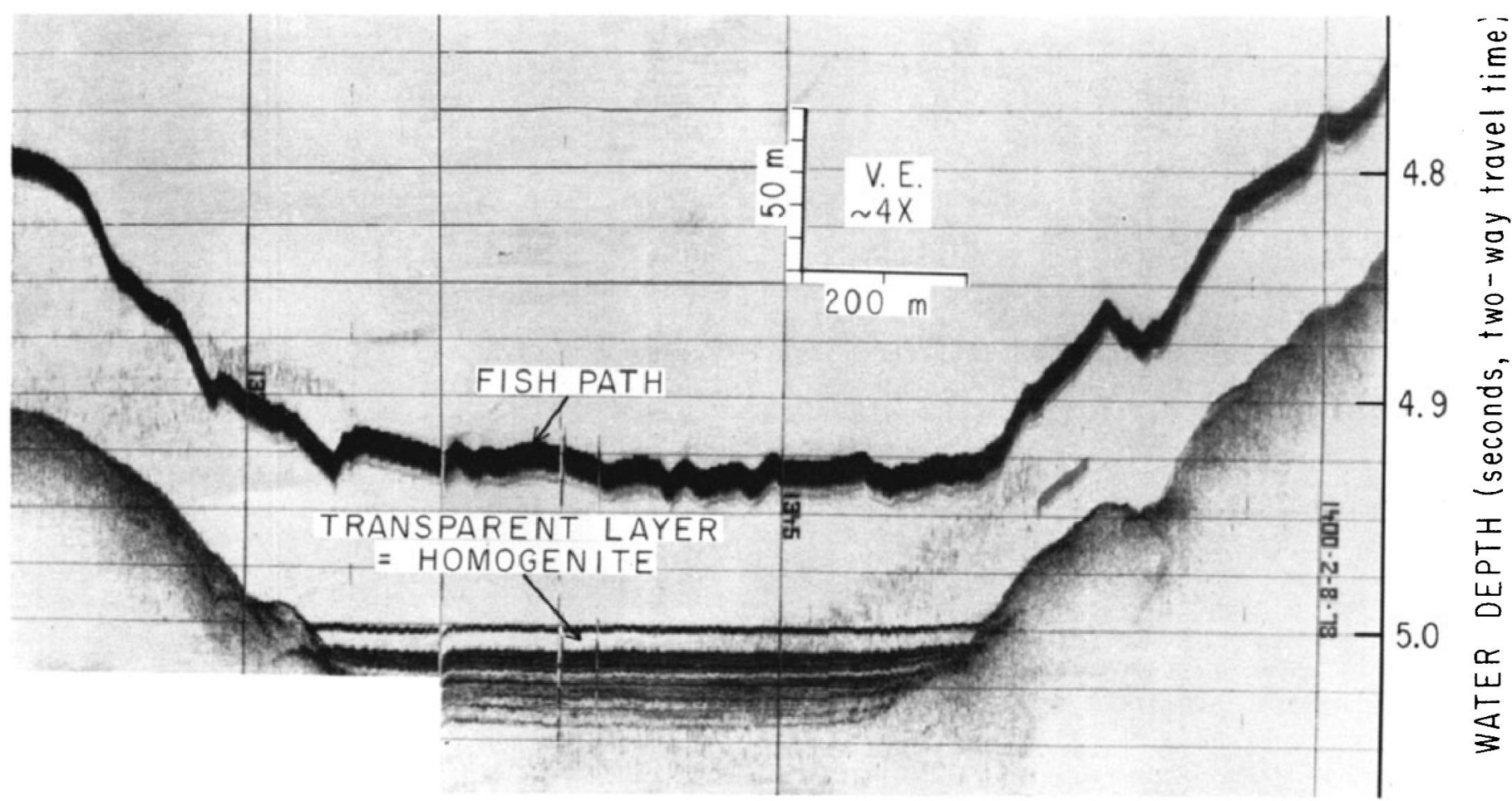

Figure 2. Near-botton 4-k Hz seismic-reflection record showing the acoustically transparent "homogenite" layer. This sediment type is flat-lying and basin filling, never found on local bathymetric highs or slopes. 


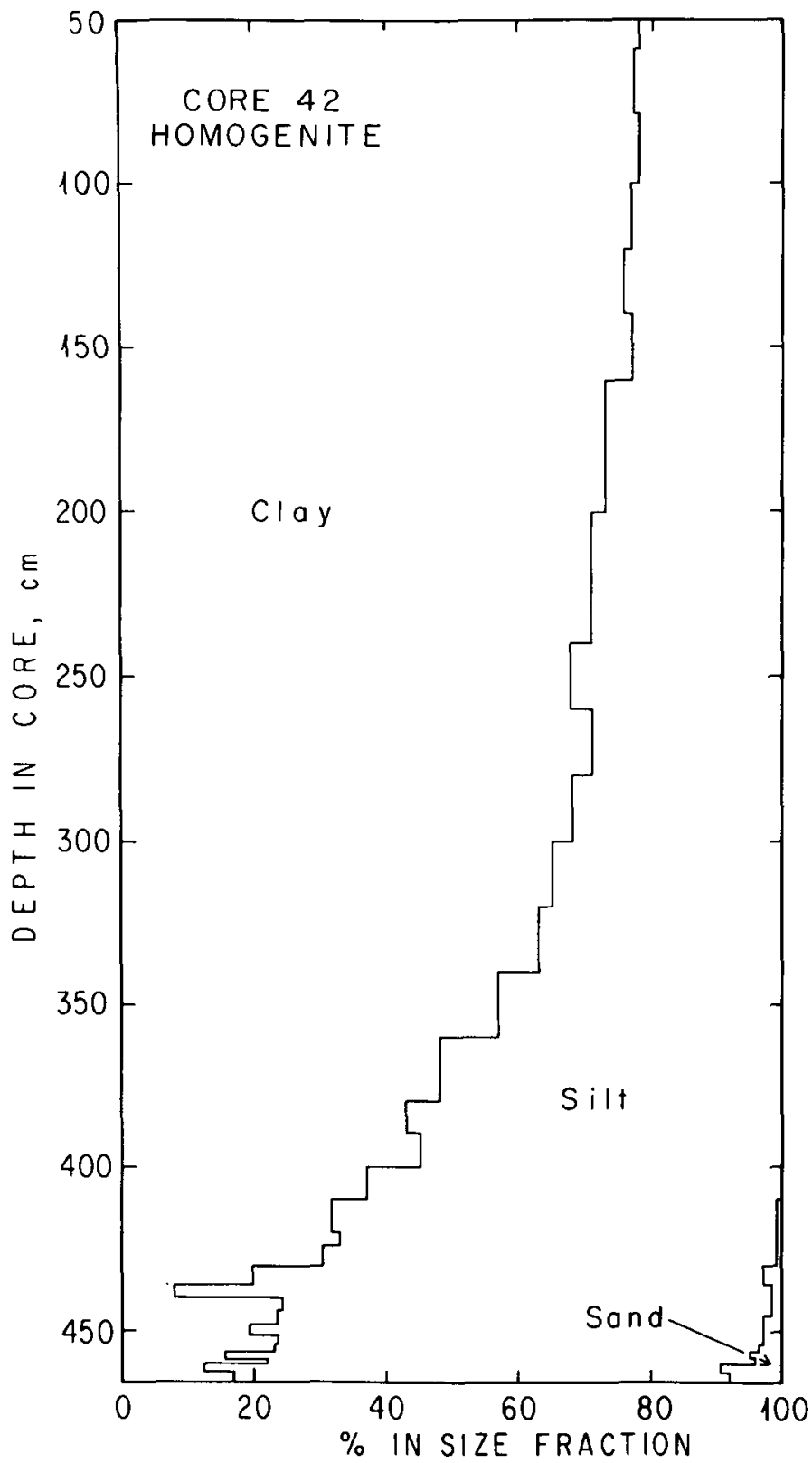

Figure 3. Grain size distribution in homogenite from core 42. The monotonic increase in fine fraction upcore is taken as evidence that the entire unit was deposited in one event dominated by gravitational settling of sediment from suspension.

sandy layer (primarily planktonic forminiferal tests), and fines rapidly upward (Fig. 3). The graded layering implies that the deposition process involved gravitational settling.

The most remarkable feature of this unit is that, except for the grain size gradation, there are absolutely no sedimentary structures discernible in the split cores or in X-radiographs throughout a thickness of as much as $7.7 \mathrm{~m}$. In this respect, this sediment type is very different fro sediments previously recovered from the eastern Mediterranean (Hsu and others, 1978; Ryan and others, 1973). The more typical cores contain numerous tephra and sapropel layers, and have changes in lithology every few centimetres. Because of its structureless nature and because initially we had no idea what genetic name to give this sediment type, we nicknamed it "homogenite."

\section{Distribution}

Of the four survey areas, the western two sites contain the acoustically transparent layer diagnostic of homogenite, whereas the eastern two sites show no trace of this sediment.

Within each of the homogenite-bearing survey areas, homogenite was found only on the basin floors. Figures 4 and 5 show the bathymetry of the Calabrian Ridge site, the distribution of the acoustic transparent layer, and the location of homogenite-bearing cores. Within the $100-\mathrm{km}^{2}$ survey area, 18 separate homogenitefilled basins were located. Homogenite is conspicuously absent from the steep basin walls and from the plateaus which separate the basins. Instead, sediments on the plateaus contain a normal eastern Mediterranean sequence of sapropels and tephras in cores (Blechschmidt and others, in press) and are seen seismically as closely spaced, subparallel reflectors. Cores from the walls are similar to plateau cores, but are frequently missing the top of the section.

Age

In every core, including those separated by $300 \mathrm{~km}$, the homogenite occupies an identical stratigraphic position (Fig. 6). It is overlain by 16 to $36 \mathrm{~cm}$ of apparently normal pelagic ooze. It is underlain by 15 to 32 additional centimetres of normal pelagic sediments and then by the S1 sapropel layer. The SI sapropel, an organic-carbon rich layer, is a widespread marker bed firmly dated at $8,000 \mathrm{yr}$ B.P. (Kidd and others, 1978). At the stratigraphic position where homogenite would be expected, plateau cores contain instead a few centimetres of fine silt-clay laminae, implying a redeposition events of less magnitude but of the same age as the homogenite event. If the post-homogenite and the pre-homogenitepost-Sl sedimentation rates are assumed equal and uniform, and the top of the $\mathrm{S} 1$ sapropel is assumed to be $8,000 \mathrm{yr}$ old, one can calculate a date for the redeposition event from the ratio of pre- to post-homogenite sediment thicknesses (Fig. 6). With one exception, these dates fall between 3100 and 4400 yr B.P.

\section{Provenance}

Two conflicting hypotheses might be suggested for the source of the homogenite. The first involves sediment transport from a distant source area, perhaps the continental shelf, by some largescale process such as a major turbidity current. This hypothesis explains the simultaneous deposition of homogenite in many $b$ asins by a single sediment transporting agent. The alternative hypothesis is that homogenite comes from an adjoining source area, and that the transport distance was less than a kilometre, from basin walls to basin floor. This hypothesis requires some widespread event capable of initiating local sediment transport in many basins simultaneously.

We prefer the adjoining source hypothesis for the following reasons:

1. The homogenite contains no allochthonous elements, such as quartz sand or unusually abundant terrigenous clay, which require a source outside the survey area. In fact, both the mineralogy and micropaleontology are a weighted average of the properties of the varying lithologies in the uppermost part of the normal plateau pelagic sequence. For example, the average organic carbon content of 43 homogenite samples from 3 cores at the Calabrian Ridge site was $0.36 \%$, which is intermediate between the organic carbon content of marls $(0.29 \%$; Cita and others, in press) and of SI sapropel (2.8\%; this study). 


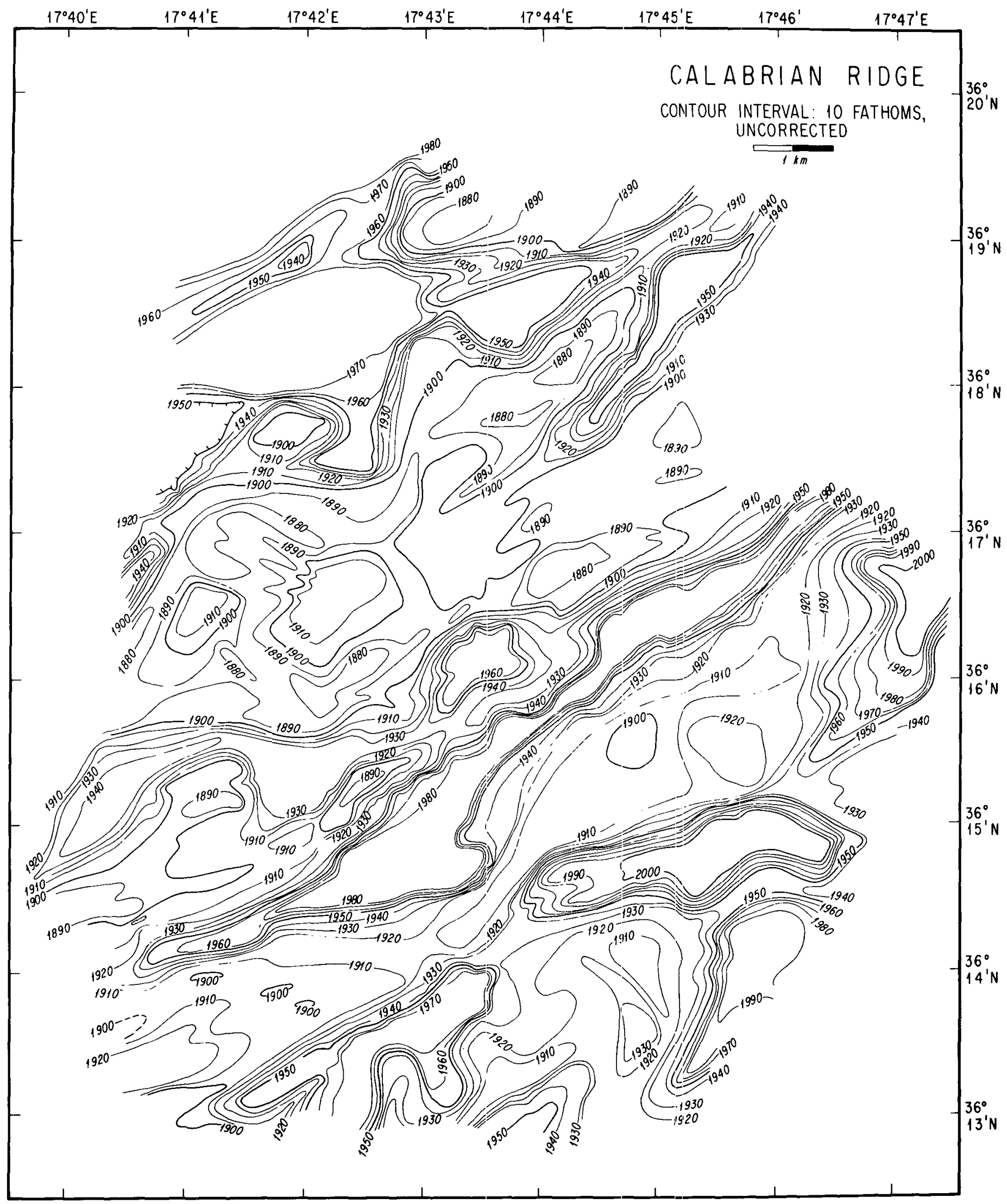

Figure 4. Bathymetric map of the Calabrian Ridge survey area. Elongate basins run subparallel to the regional trend of the Calabrian Ridge. These troughs have flat bottoms and steep walls (up to $45^{\circ}$ ) and are separated by flat or gently dipping plateaus. Notice the small scale; each basin is approximately $1 \mathrm{~km}$ across. 


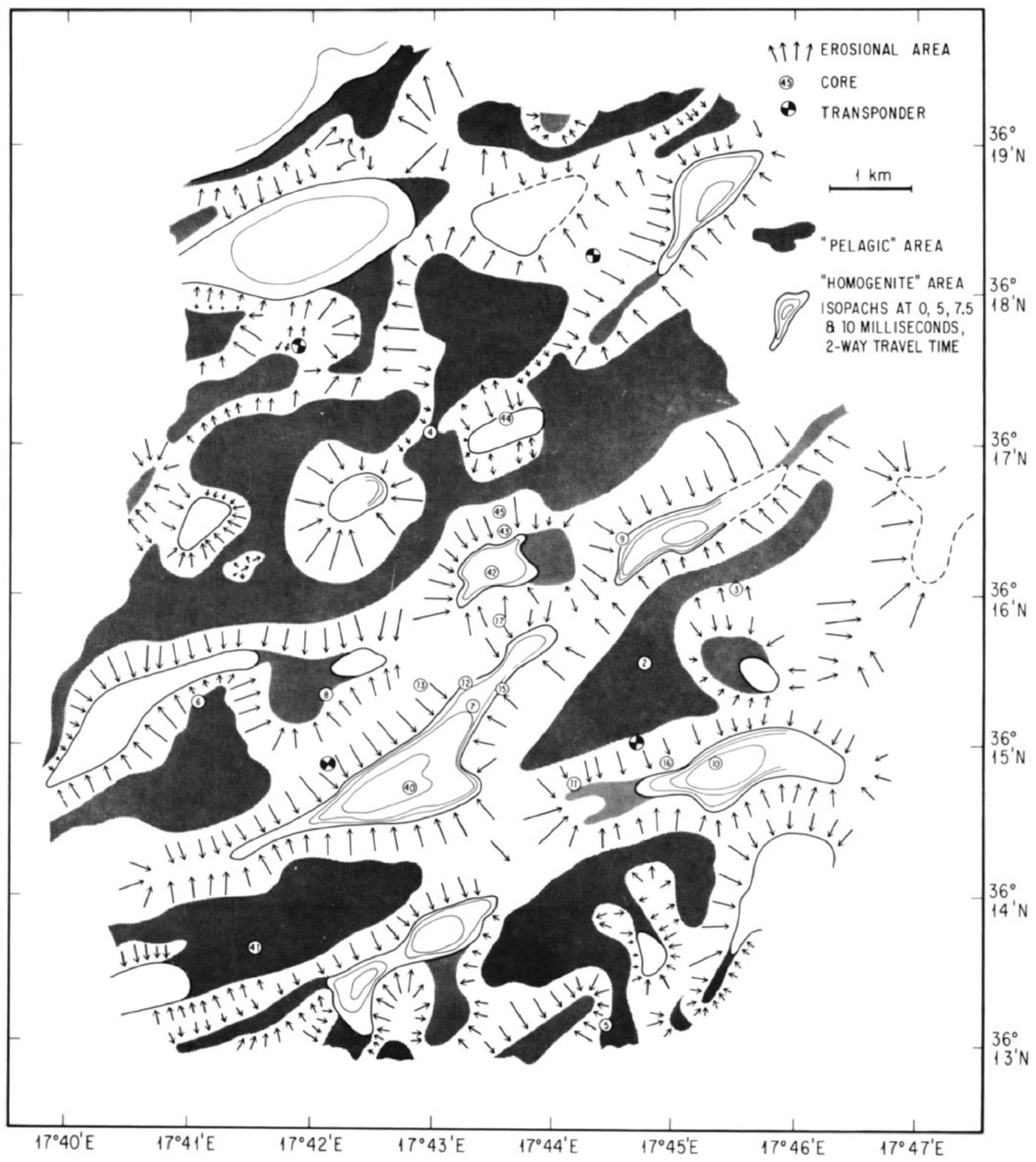

Figure 5. Distribution of the acoustically transparent layer and of homogenite-bearing cores at the Calabrian Ridge site. Homogenite is found only in the basins. The "pelagic" facies, found on plateaus, is characterized by closely spaced subparallel reflectors on 4-kHz records and a normal Mediterranean sequence of sapropels and tephras in cores. The "erosional" facies, found on steep slopes, is reverberant on seismic-reflection records. Piston cores from the "erosional" facies lack the top of the section. 


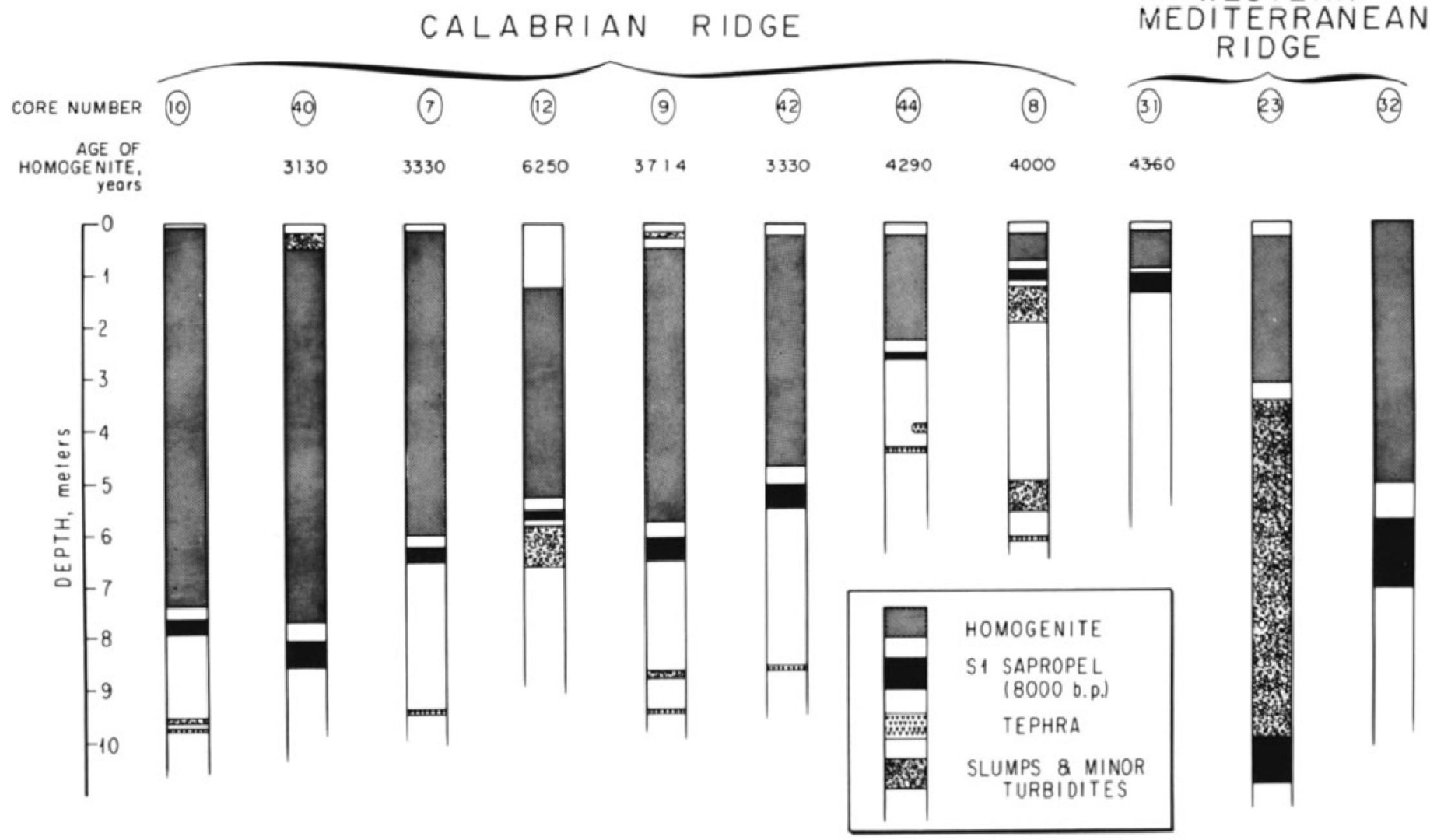

Figure 6. Simplified core logs for homogenite-bearing cores. In every core, the homogenite occupies the same stratigraphic position with respect to the $\mathrm{S} 1$ sapropel and the top of the core. The age of the homogenite has been calculated assuming the homogenite was deposited instantaneously, that pelagic sedimentation rate above and below the homogenite was uniform, and that the age of the top of the $S 1$ sapropel is $8,000 \mathrm{yr}$. Where the core top was disturbed in coring, no rate or age is given. Slumps and minor turbidites were omitted in the age and sedimentation rate calculations. In plateau cores $2,5,6$, and 45 (not shown), the hornogenite's stratigraphic position is occupied by a thin layer of silt-clay laminae, with apparent age calculated with respect to the S1 layer of $4,200,3,000,3,520$, and 3,440 yr, respectively.

2. We have succeeded in manufacturing an artificial homogenite from local material. A subsection of the top $150 \mathrm{~cm}$ of the type pelagic core from the Calabrian Ridge site (core 45; Blechschmidt and others, in press), which contains a sapropel layer, a tephra layer, and multicolored marls and oozes, was placed in a core liner with sea water, agitated, and then allowed to settle gravitationally. A thin graded base developed, and the distinctive homogenite color replaced the varied palette of the original sediment.

3. Cores from the basin walls apparently lack sediment from the time interval just prior to the deposition of homogenite (Blechschmidt and others, in press). Figure 7 shows the core logs from the trigger cores from the basin walls at the Calabrian Ridge site. The top 10 to $20 \mathrm{~cm}$ in each core can be correlated well. Below that, each core has an unconformity underlain by generally noncorrelatable strata of varying age. We believe this hiatus may represent in part the erosion of the sediment which ultimately formed homogenite.

4. The volume of homogenite within a given basin is roughly proportional to the postulated source area. The volume of homogenite in each basin at the Calabrian Ridge site was calculated from the isopachs in Figure 5, calibrated for appropriate sound velocity from cores located near Deep Tow tracks. The area was divided into "watersheds" based on the bathymetry. Within each watershed the area which belonged to the erosional acoustic facies (characterized by reverberant acoustic return) was measured. The correlation coefficient for a linear regression of homogenite volume onto alleged source area was $r^{2}=0.74$ for 16 basins, which is significant at $=[0.01$.

If the adjoining source is accepted, we may then speculate on the thickness of the cover stripped off the source area. Several lines of reasoning suggest that the depth of erosion averaged $\sim 1 \mathrm{~m}$. First, the ratio between the volume of homogenite in a given basin at the Calabrian Ridge site and its alleged source area is $\sim 1 \mathrm{~m}$. Second, the average organic carbon content of homogenite $(0.36 \%)$ suggests that it is a mixture of approximately 3 parts sapropel (of organic carbon content $2.8 \%$ ) to 104 parts marl (of organic carbon content $0.29 \%$ ); thus, if the $S 1$ sapropel in the source area was $3 \mathrm{~cm}$ thick, as it is in the type pelagic core 45 , homogenizing the top $108 \mathrm{~cm}$ of source area sediment would have produced a sediment of appropriate organic carbon content. Finally, the average carbonate content of $\mathbf{4 3}$ homogenite samples from three Calabrian Ridge cores was $47 \%$. This is much higher than the average carbonate content of the type pelagic core (Cita and others, in press, their Figure 4), but is consistent with the elevated carbonate content of the warm $Z$ 
GRAVITY CORES FROM BASIN WALLS

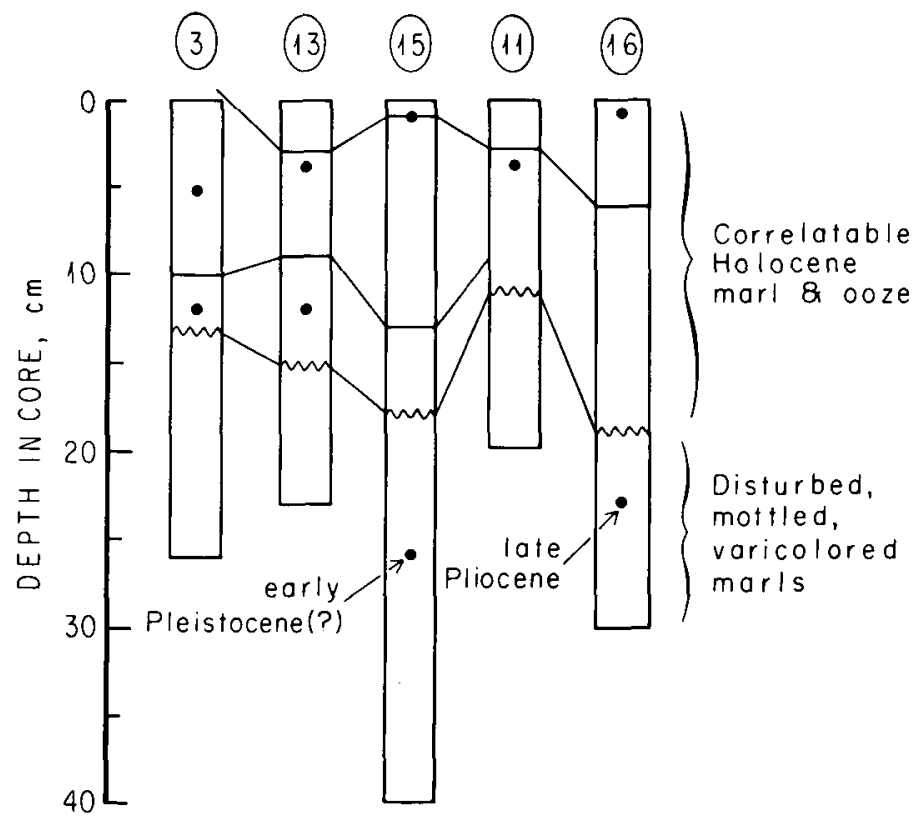

Figure 7. Core logs for the trigger (gravity) cores from basin walls at the Calabrian Ridge site. The unconformity below the top 10 to $20 \mathrm{~cm}$ of the marl is interpreted as the source of the material which became the homogenite. Dots mark samples for which foraminiferal ages were determined. All are Holocene, except where otherwise noted.

climatic zone which occupies approximately the uppermost $90 \mathrm{~cm}$ of the type section.

Although on the average the homogenite-forming mechanism tapped a 1-m-thick source, the occasional presence of older reworked nannofossils (G. Blechschmidt, 1980, personal commun.) implies that locally erosion cut much deeper.

\section{MECHANISM OF FORMATION}

\section{Requirements}

We have established that the homogenite is a resedimented deposit, transported from basin walls to basin floors, deposited in a process involving gravitational settling. We now require a triggering mechanism which is capable of simultaneously initiating local sediment transport in widely separated basins.

The lithology and setting of the homogenite place the triggering mechanism within narrow constraints of timing, spacing, and force. First, this event was short-lived, unique in the last $8,000 \mathrm{yr}$, and occurred between 4,400 and 3,100 yr B.P. Second, it was felt in every basin at the western two sites, but apparently not at either of the eastern sites. Finally, it was strong enough to cause erosion of $\sim 1 \mathrm{~m}$ of sediment. The mechanisms considered are (1) an earthquake and (2) a tsunami.

\section{Earthquake}

Earthquakes can cause slope failure and landslides by liquefaction of sediment. Under cyclic loading of the earthquake p-wave, the pore pressure of interstitial water gradually increases until the pore pressure exceeds the confining pressure and the soil or sediment loses strength and can easily be displaced long distance. On land, earthquakes of magnitudes 5.3 to 8.2 have caused liquefaction $1 \mathrm{mi}$ to hundreds of miles from the epicenter (Seed, 1968). The magnitude of earthquake required to cause liquefaction depends on distance from the epicenter, soil type, soil density, initial confining pressure, intensity and duration of ground shaking, and initial slope (Seed and Idriss, 1971). Unfortunately, the predictive capabilities for liquefaction potential developed by soil engineers cannot be directly applied to submarine unconsolidated clays, and so we cannot pinpoint exactly what magnitude earthquake would be required to cause submarine slides. However, the best-documented submarine turbidity current, on the Grand Banks in 1929, followed a 7.5 magnitude earthquake (Heezen and Ewing, 1952), suggesting that submarine slides are triggered by earthquakes of approximately the same magnitude as terrestrial slides.

Situated at a convergent plate margin, the Mediterranean and Calabrian Ridges are indeed seismically active Comninakis and Papazachos, 1972; Papazachos and Comninakis, 1971). A catalogue of earthquake shocks in the Aegean (Komlos and others, 1978) shows that there was an earthquake in the appropriate time frame ( $\sim 500$ yr B.P.) The magnitude, date, and epicenter have been estimated based on the extent of destruction at archaeological sites on Crete. However, the epicenter at approximately $35^{\circ} \mathrm{N}, 26^{\circ} \mathrm{E}$ was midway between the eastern and central Mediterranean sites, where homogenite is not observed, and nearly $500 \mathrm{~km}$ from the nearest observed homogenite. Furthermore, the 3,500 yr B.P. earthquake was not unique; there have been five earthquakes of comparable or larger magnitude in the Aegean since 1966.

\section{Tsunami}

The collapse of the caldera of the volcano Santorini during a major eruption 3,500 yr B.P. caused a huge tsunami which inundated surrounding islands and is recorded in the lore of many circum-Mediterranean cultures (Yokoyama, 1978; Marinos and Melidonis, 1971; Meszaros, 1978). Perhaps the oscillatory nearbottom currents accompanying the tsunami were sufficient to stir sediment on the walls of the basins into suspension. Alternatively, the pressure pulse under the wave might have caused liquefaction in a manner similar to that which occasionally causes slope failure under wind waves in shallow water. Was either of these mechanisms strong enough to initiate large-scale sediment transport?

\section{Near-Bottom Oscillating Current}

First, we shall estimate the velocity of the bottom currents at each of the four survey sites under a tsunami whose source was the Santorini caldera. These estimated velocities will then be compared with the current velocity required to initiate sediment transport. (The equations which follow come from Airy wave theory, discussed in physical oceanography texts such as Kinsman, 1965, or Wiegel, 1964.)

Because all tsunamis are shallow-water waves with wavelength much larger than the water depth, the speed of the wave depends only on the water depth:

$$
c=\sqrt{g d},
$$

where $\mathrm{c}=$ wave group velocity; $\mathrm{g}=$ acceleration due to gravity; and 


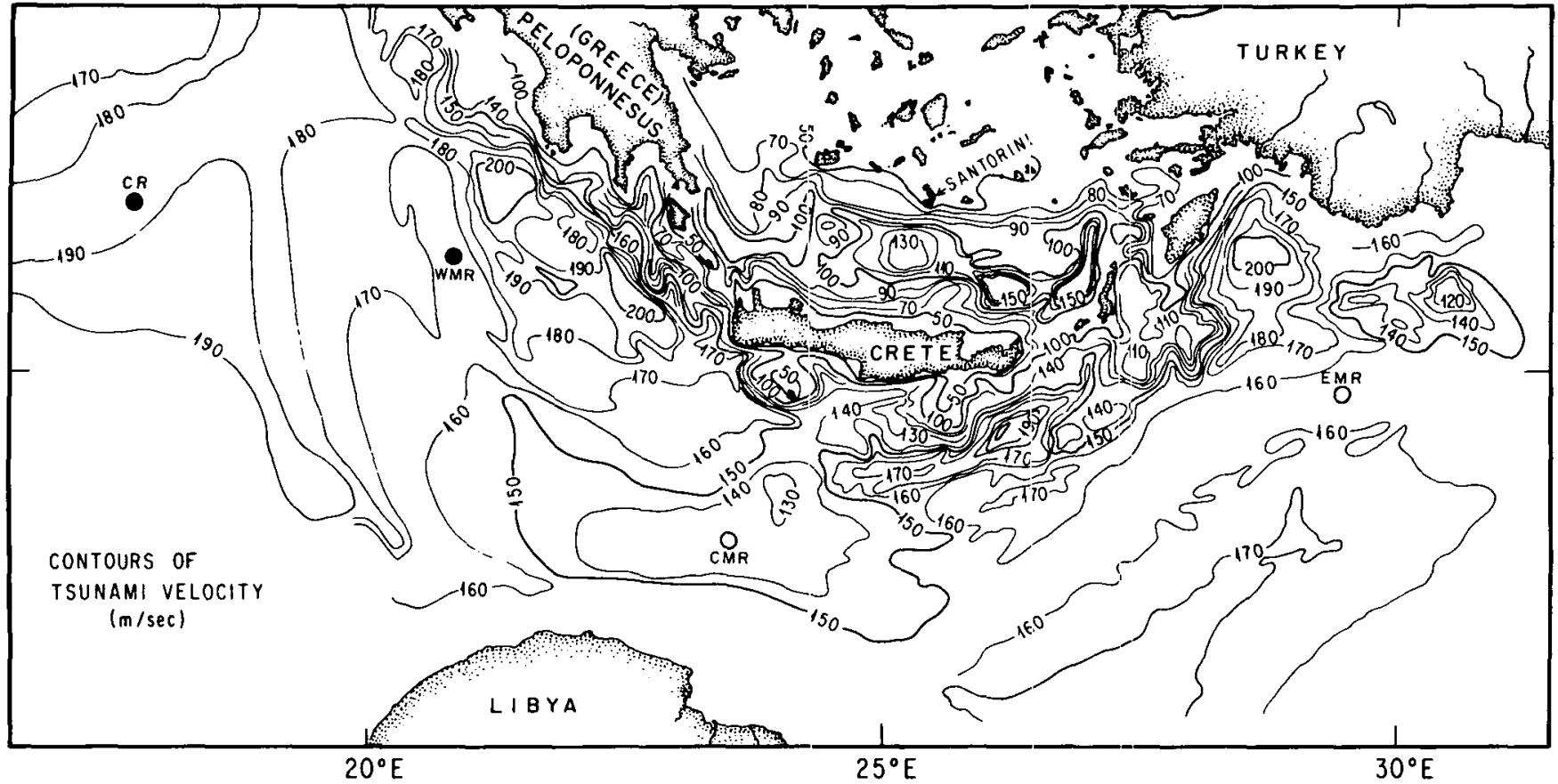

Figure 8. Contours of equal tsunami velocity assuming that a isunami is a shallow-water wave (wavelength $>>$ water depth) with velocity dependent only on water depth.

$\mathrm{d}=$ water depth. Therefore, tsunami velocity can be contoured (Fig. 8) directly from a bathymetric map, or calculated for any specific site (Table 1). As the tsunami advances, the parts of each wave crest passing over deeper water move faster than those segments moving over shallower water, and wave energy is focused toward shallow areas and away from deep areas. Figure 9 shows the ray paths or wave crest orthogonals originating at $5^{\circ}$ azimuth intervals from a point source at Santorini and traveling with the velocities shown in Figure 8. Figure 9 was constructed by assuming a 10 $\mathrm{m} / \mathrm{sec}$ velocity discontinuity at each velocity contour crossing, and applying Snell's law:

$$
\frac{\sin \alpha_{1}}{\sin \alpha_{2}}=\frac{c_{1}}{c_{2}}
$$

where $c_{1}=$ velocity before refraction; $c_{2}=$ wave velocity after refraction; $\alpha=$ angle between the incoming ray and the perpendicular to the contour line, and $\alpha_{2}=$ angle between the outgoing ray and the perpendicular to the contour line. The radiating lines are everywhere orthogonal to the wave crests; and, assuming a point energy source, the wave possessed equal energy along any wave crest between adjacent orthogonals.

An assumption implicit in this ray-tracing approach is that the wavelength is smaller than the scale of the velocity inhomogeneities in the medium. A tsunami is larger than many bathymetric features, so some diffraction of waves around obstacles may be expected, and the focusing and defocusing effects may actually be less extreme than shown in Figure 9.

Although the details of Figure 9 are sensitive to minor changes in the bathymetry, particularly near the source, the over-all picture is indisputable. The wave energy originally directed due east or west

TABLE 1. TSUNAMI PROPERTIES

\begin{tabular}{|c|c|c|c|c|c|c|c|}
\hline Site & $\begin{array}{l}\text { Water } \\
\text { depth } \\
\text { (d) }\end{array}$ & $\begin{array}{l}\text { Wave * } \\
\text { speed } \\
\text { (c) }\end{array}$ & $\begin{array}{l}\text { Wave } \dagger \\
\text { length } \\
\text { (L) }\end{array}$ & $\begin{array}{c}\text { Wave } \ddagger \\
\text { orthogonal } \\
\text { separation (b) }\end{array}$ & $\begin{array}{l}\text { Wave ** } \\
\text { height } \\
\text { (H) }\end{array}$ & $\begin{array}{l}\text { Near-bottom }+\dagger \\
\text { current speed } \\
\text { (u max) }\end{array}$ & $\begin{array}{c}\text { Magnitude }+\ddagger \\
\text { of pressure pulse } \\
(\Delta \mathrm{P} \text { max })\end{array}$ \\
\hline $\begin{array}{l}\text { Eastern Mediterranean } \\
\text { Ridge }\end{array}$ & $2,400 \mathrm{~m}$ & $153 \mathrm{~m} / \mathrm{sec}$ & $137 \mathrm{~km}$ & ? large & small & small & small \\
\hline $\begin{array}{l}\text { Central Mediterranean } \\
\text { Ridge }\end{array}$ & $1,810 \mathrm{~m}$ & $133 \mathrm{~m} / \mathrm{sec}$ & $120 \mathrm{~km}$ & $1,000 \mathrm{~km}$ & $1.9 \mathrm{~m}$ & $6 \mathrm{~cm} / \mathrm{sec}$ & $0.9 \times 10^{5}$ dynes $/ \mathrm{cm}^{2}$ \\
\hline $\begin{array}{l}\text { Western Mediterranean } \\
\text { Ridge }\end{array}$ & $2,900 \mathrm{~m}$ & $168 \mathrm{~m} / \mathrm{sec}$ & $151 \mathrm{~km}$ & $10 \mathrm{~km}$ & $17 \mathrm{~m}$ & $49 \mathrm{~cm} / \mathrm{sec}$ & $8.5 \times 10^{5}$ dynes $/ \mathrm{cm}^{2}$ \\
\hline
\end{tabular}

* $\mathrm{c}=\sqrt{\mathrm{gd}}$

$\dagger \quad \mathrm{L}=\mathrm{cT}$; assume period $\mathrm{T}=15 \mathrm{~min}$

$\ddagger$ from Figure 2

** $H_{1}=H_{o}\left(b_{o} / b_{1}\right)^{1 / 2}\left(d_{0} / d_{1}\right)^{1 / 4}$ $\dagger \dagger \mathrm{u}_{\max }=\frac{\mathbf{H}}{2 \mathrm{~d}} \frac{\sigma}{\mathbf{K}}=\frac{\mathrm{H}}{2 \mathrm{~d}} \sqrt{\mathrm{gd}}$

$\ddagger \Delta \mathrm{P}_{\max }=\rho \mathrm{g} \mathrm{H} / 2$ 


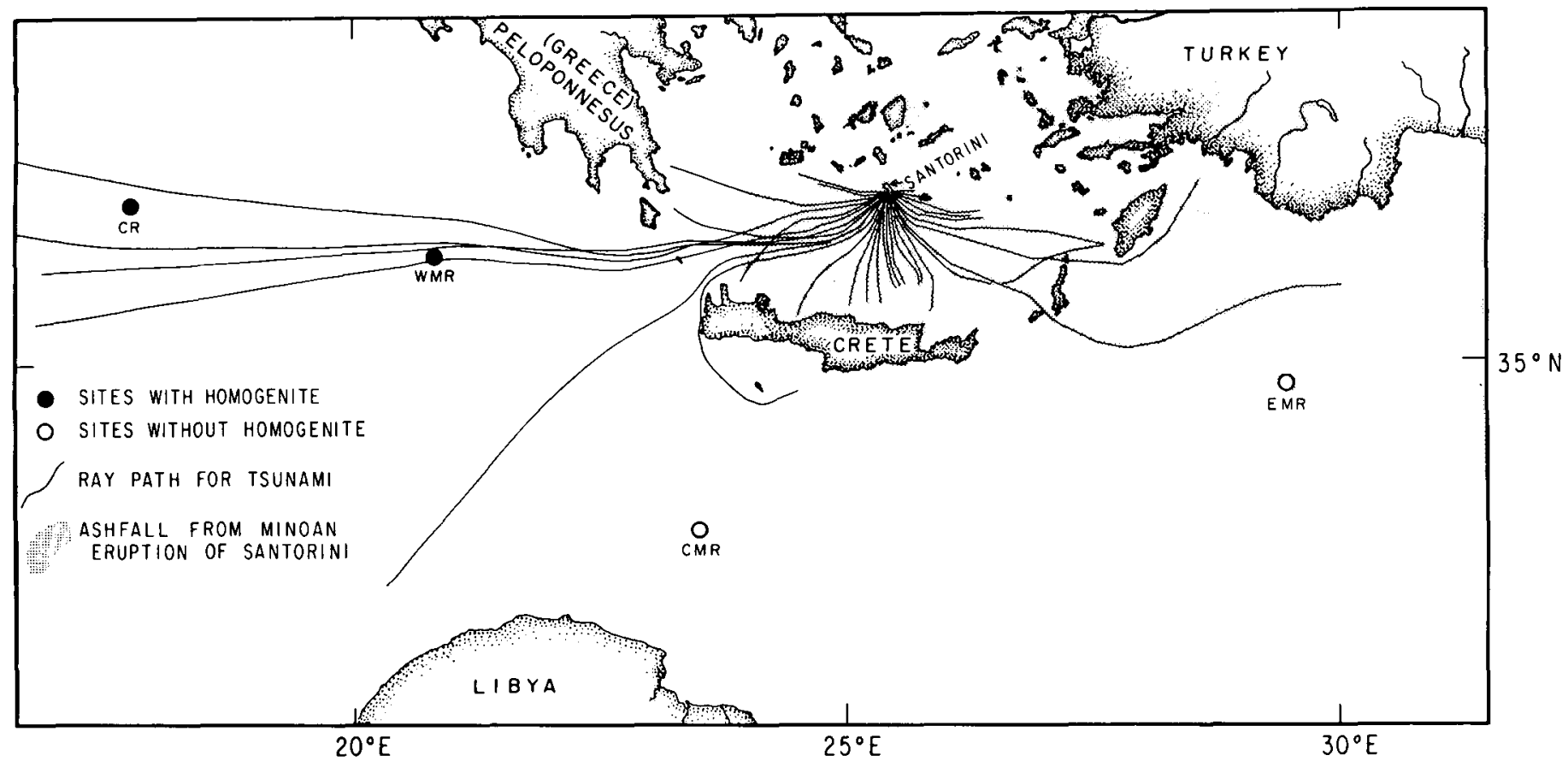

Figure 9. Ray paths for a tsunami originating as a point source at Santorini were determined by applying Snell's law at each contour crossing on the tsunami velocity chart of Figure 8. A disproportionate amount of the tsunami energy passes just west of Crete and toward our western survey sites. The eastern survey sites receive relatively little wave energy. The shaded area received ash fall from the 3500 yr B.P. eruption of Santorini (Keller, 1978; Watkins and others, 1978).

from Santorini was refracted along the coastline parallel to the bathymetric contours, and that directed due south encountered Crete. The energy originally radiated into the southwest quadrant passed over a shallow area which acted like an optical convex lens and focused a disproportionate amount of energy through the passage west of Crete and outward toward the western two sites. In contrast, the energy originally radiated to the southeast encountered a deep area, like a concave lens, which redirected energy south and east, allowing only much diminished waves to travel toward the eastern Mediterranean Ridge site. The central Mediterranean Ridge site, sheltered behind Crete, received only attenuated waves extensively refracted around the southwest corner of the island.

In fact, Santorini was not a point energy source, since the caldera collapse was not complete. The caldera remnant is now open to the southwest, and the tsunami pulse must have been stronger in that direction. If so, the amount of energy reaching the western sites would have been proportionately greater than that reaching the easternmost site.

The height of the wave at any place on a refraction diagram can be calculated if the height at one point is known, by:

$$
H_{1}=H_{o}\left(\frac{b_{0}}{b_{1}}\right)^{1,2}\left(\frac{d_{0}}{d_{1}}\right)^{1 / 4} \text {, }
$$

where $\mathbf{H}=$ wave height; $\mathbf{d}=$ water depth; $\mathbf{b}=$ distance between orthogonals; and subscripts 1 and o refer to two different locations. This approach is based on the assumption that the total wave energy between rays remains constant over time. Where the ray geometry includes extreme convergence or divergence, as is the case with tsunamis over complex bathymetry, or where the initial wave energy is subsequently redistributed by dispersion (as is the case with tsunamis; Munk, 1947; Ward, 1980) this approach must be considered a first approximation only. Using this technique, Yokoyama (1978) estimated the original height of the Santorini tsunami as between 50 and $68 \mathrm{~m}$. We shall use the more conservative estimate: $\mathbf{H}_{0}=50 \mathrm{~m}$. It is necessary to define where the edge of Santorini was in order to know at what water depth and orthogonal separation Yokoyama's $50-\mathrm{m}$ high wave was found. We have chosen the 200-m contour which outlines the island with a circumference of $315 \mathrm{~km}$, thus giving $b_{o}=4.4 \mathrm{~km}$. Using values of $b_{1}$ and $d_{1}$ as in Table 1 , the height of the tsunami is estimated at $17 \mathrm{~m}$ at the western Mediterranean Ridge site, $6.9 \mathrm{~m}$ at the Calabrian Ridge site, and $1.9 \mathrm{~m}$ at the central Mediterranean Ridge site. The wave height at the easternmost site cannot be calculated from the refraction daigram shown because the site is not surrounded by two orthogonals, but wave height must be smaller than at the central Mediterranean Ridge site because both the water depth and orthogonal separation are larger at the eastern site.

The maximum horizontal component of velocity under a shallow water wave, experienced under the crests and troughs of the wave, is given by:

$$
\mathrm{u}_{\max }=\frac{\mathrm{H}}{2 \mathrm{~d}} \frac{\sigma}{\mathrm{K}}
$$

where $\mathbf{u}=$ water particle velocity in the horizontal direction; $\mathrm{d}=$ water depth, $\mathrm{H}=$ wave height, $\mathrm{K}=2 \pi / \mathrm{L} ; \mathrm{L}=$ wavelength; $\sigma=2 \pi / \mathrm{T} ; \mathrm{T}=$ wave period. By setting $\mathrm{L}=\mathrm{cT}$ ( $\mathrm{c}=$ wave speed again) and $c=\sqrt{g d}$, the expression for $u_{\max }$ can be reduced to the known quantities of water depth and wave height:

$$
u_{\max }=\frac{H}{2 d} \sqrt{g d} .
$$

This expression gives a near-bottom maximum water velocity of 49 
$\mathrm{cm} / \mathrm{sec}$ at the western Mediterranean Ridge, $19 \mathrm{~cm} / \mathrm{sec}$ at the Calabrian Ridge, $6 \mathrm{~cm} / \mathrm{sec}$ on the central Mediterranean Ridge, and less than $6 \mathrm{~cm} / \mathrm{sec}$ on the eastern Mediterranean Ridge.

Are any or all of these velocities sufficient to stir sediment into suspension? The prediction of the critical erosion velocity for submarine sediments with a substantial clay fraction is far from a trivial problem Partheniades, 1965; Task Committee on Erosion of Cohesive Sediments, 1968; Einsele and others, 1974; Lonsdale and Southard, 1974; Southard and others, 1971). Among the variables which influences erosion are the strength of the electronchemical bonds between clay particles (in turn dependent on presence of electrolytes, mineralogy, temperature, and $\mathrm{pH}$ ); bed roughness; water content; sediment shear strength; grain size distribution; percentage clay; duration and steadiness of current; activity of benthic organisms; and slope of the bed. Where theory fails, empirical flume measurements on critical erosion velocity of calcareous ooze (Southard and others, 1971) and abyssal red clay (Lonsdale and Southard, 1974) may be illuminating. As shown in Figure 10, cal-

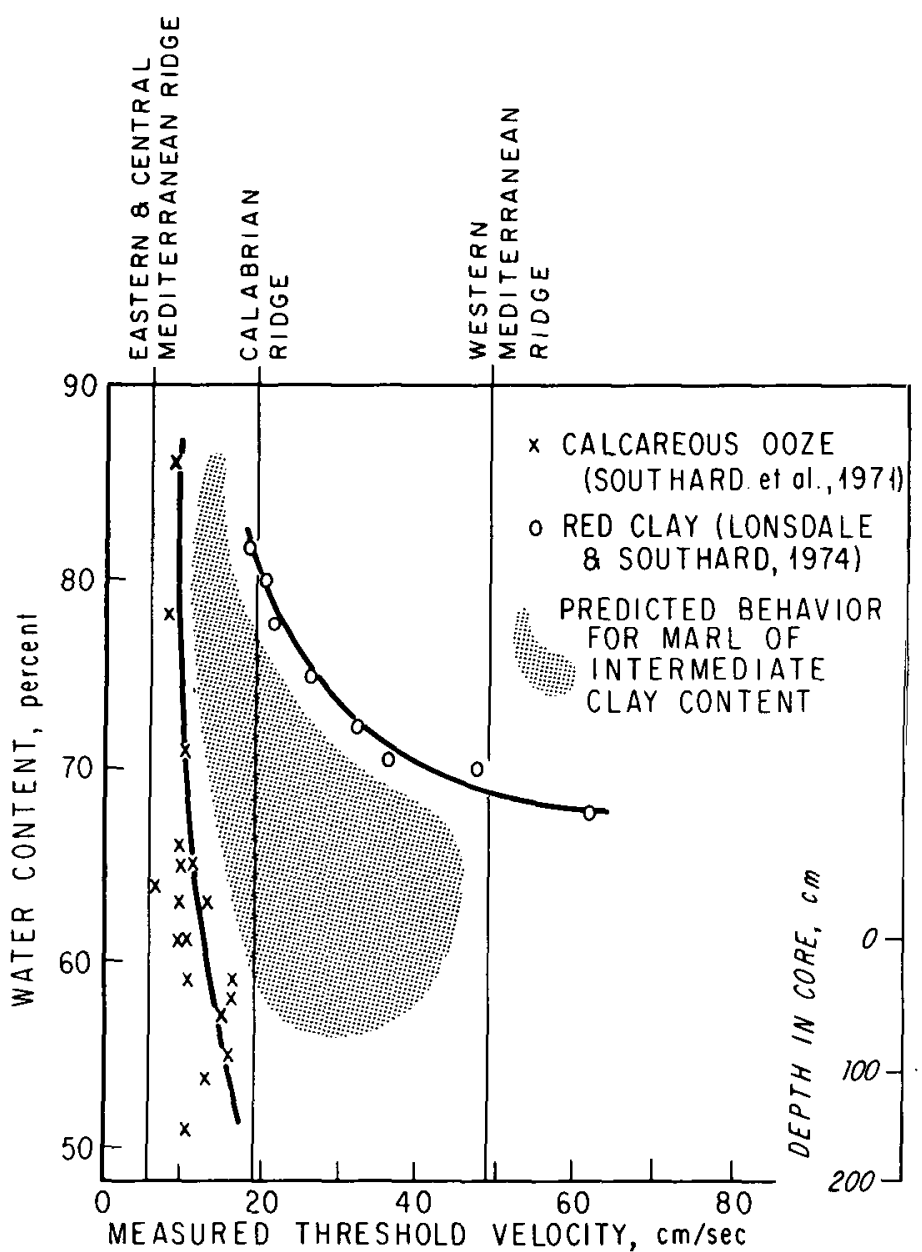

Figure 10. Experimentally derived threshold erosion velocities for abyssal sediments are compared with the maximum tsunamiinduced near-bottom current velocity at each survey site. Sites EMR and CMR are clearly below the erosion threshold; Site WMR is clearly in the erosional regime; and Site $C R$ is on the borderline. The right vertical axis shows the depth in a nearby core (A-3; Keller and Lambert, 1973) at which the water content on the left vertical axis is found. careous ooze in a 6-cm-ideep flume begins to erode under a current of 8 to $19 \mathrm{~cm} / \mathrm{sec}$; red clay resists erosion until current velocity exceeds 19 to $60 \mathrm{~cm} / \mathrm{sec}$. In both cases, threshold velocity is dependent on water content. Increased botton roughness also decreases threshold velocity.

Our sediment, intermediate in clay content between the two experimental sediment types, should exhibit intermediate erosion characteristics. Even allowing for considerable uncertainly in threshold velocity, it is clear that the maximum tsunami-induced nearbottom current velocity at the eastern sites is well below the critical erosion velocity, whereas at site WMR the velocity is more than sufficient to put sediment into suspension. Site $C R$ lies on the border line. On the plateaus, which are a close approximation to the planar bed of the flume experiments, suspension would be minor, sufficient to cause the fine silt-clay laminae observed in plateau cores. However, on the steep walls of the basins where bed roughness (judged from photographs) is greater and sediment rests close to its critical angle of repose, extensive sediment transport might be expected.

Strictly speaking, the passage of a tsunami does not meet our criteron that the triggering mechanism be a single instanteous event. Rather, the current velocity increases from near-zero to $u_{\max }$, decreases to zero, increases back to $u_{\max }$ in the opposite direction, and drops again to zero, in one wave period. The nature of the resulting sediment layer depends upon whether the sediment settles out or remains in suspension in the relatively still intervals. This in turn depends upon the sediment-settling velocity and the time interval between high-speed currents. We have no direct knowledge of the period of the Santorini tsunami, but a similar event occurred in 1883 when the caldera of Krakatoa collapsed (Hedervari, 1976). Analogy with the Krakatoa tsunami suggests that the Santorini tsunami was characterized by a period of about $15 \mathrm{~min}$ (Boutelle, 1884; Baird, 1883), or $7.5 \mathrm{~min}$ between peak current velocities. Our experience in attempting, to create an artificial homogenite was that the water-slurry interface sank less than $1 \mathrm{~cm}$ in the first $10 \mathrm{~min}$ after agitation stopped, so that much of the sediment stirred into suspension during one episode of high current velocity would remain suspended during the quiet interlude. Repeated stirring by currents from opposing directions could create a water-sediment mixture which might settle into a single thick-graded bed.

There is a severe volume problem with using current scour alone to create the observed homogenite. Shear stress acting only on the free upper surface of the sediment column probably cannot put the requisite volume of sediment into suspension. Consider the small basin from which core 42 was raised, in the center of the Calabrian Ridge site. This basin contains approximately $650 \mathrm{~m}^{3}$ of homogenite, or $1.6 \times 10^{9} \mathrm{~g}$ of homogenite, assuming porosity profile of core A-3 (Keller and Lambert, 1973) and grain density of 2.6 $\mathrm{g} / \mathrm{cm}^{3}$. The volume of this basin, up to its lowest sill, is approximately $10^{5} \mathrm{~m}^{3}$. Thus, if the homogenite in this basin were dispersed throughout the water column, the concentration of suspended sediment would be $1.6 \times 10^{-2} \mathrm{~g} / \mathrm{cm}^{3}(16,000 \mathrm{mg} / 1)$. Such concentrations are not observed in current-generated suspensions. For comparison, in a study of suspended sediment in estuarine tidal currents exceeding $50 \mathrm{~cm} / \mathrm{sec}$, the highest suspended concentration observed was less than $300 \mathrm{mg} / 1$ (Schubel and others, 1971). The muddiest current-stirred water ever seen in the deep sea, in the HEBBLE area south of Nova Scotia, contained only 10 to $12 \mathrm{mg} / 1$ of suspended sediment (Kerr, 1980). Even at $300 \mathrm{mg} / 1$, the homo- 
genite in Botticelli basin would fill the entire water column nearly to the sea surface.

\section{Pressure Pulse}

The passage of a surface wave causes cyclic increases and decreases of pressure on the sea floor and within the sediment. In shallow water, the pressure train under wind waves has been observed to cause liquefaction of sediment (Wright and Dunham, 1972; Henkel, 1970; Dalrymple, 1979; Mitchell and others, 1972; Marshall, 1978). This triggering mechanism is similar to the discarded earthquake hypothesis in that cyclic changes of pressure attempt to compress the sediment-water mixture faster than sediment permeability allows pore water to escape. Pore pressure rises. When the pore pressure exceeds the overburden pressure, spontaneous failure can occur. Liquefied sediments have a low resistance to shear, and can flow as much as a kilometre over slopes of a few degrees (Lowe, 1976). Because the pressure pulse acts within the sediment column rather than at the sediment-water interface, a larger volume of sediment can be mobilized by this mechanism than by near-bottom currents.

This mechanism requires that the time for dissipation of axcess pore pressure be large compared with the period of the cyclic pressure pulse. Because the period of a tsunami is approximately 100 times the period of a storm wave, and 1,000 times the period of a seismic wave, this requirement is not to be taken for granted. However, Einsele and others (1974, Fig. 4) found that dissipation of excess pore pressures in clays took days rather than the minutes that elapse between pressure pulses under a tsunami.

Liquefaction also requires a sufficient number of repetitions of the stress cycle. Between 10 and 30 cycles caused liquefaction of sand in laboratory tests (Seed and Idriss, 1971). Although we cannot know the length of the Santorini tsunami wave train, analogy with the Krakatoa tsunami (Boutelle, 1884) suggests there were probably a dozen or more stress cycles.

The change in pressure on the bottom under a passing wave is given by:

$$
\Delta \mathrm{P}=\rho \mathrm{g} \frac{\mathrm{H}}{2} \frac{1}{\cosh 2 \pi \mathrm{d} / \mathrm{L}} \cos 2 \pi\left(\frac{\mathrm{x}}{\mathrm{L}}-\frac{\mathrm{t}}{\mathrm{T}}\right),
$$

where the terms are as defined above with the addition of $\rho=$ water density, $x=$ distance, and $t=$ time. Because this expression is dependent upon wavelength, the pressure train from a tsunami of relatively small amplitude might be felt on the bottom, but that of a towering storm wave would not. When $L>d$, the cosh term goes to one, and the maximum change in pressure is given simply by:

$$
\Delta \mathbf{P}_{\max }=\rho \mathbf{g} \frac{\mathbf{H}}{2} .
$$

For the wave heights calculated earlier, $\bigwedge \mathrm{p}_{\max }$ is less than or equal to $0.9 \times 10$ s dynes $/ \mathrm{cm}^{2}$ at sites EMR and CMR, $3.5 \times 10^{5}$ dynes $/ \mathrm{cm}^{2}$ at the Calabrian Ridge site, and $8.5 \times 10^{5} \mathrm{dynes} / \mathrm{cm}^{2}$ at site WMR. Are any or all of these pressure changes sufficient to cause liquefaction and initiate sediment motion? This problem is perhaps even more complex than the prediction of critical erosion velocity, because the mechanism of failure is not clearly understood. Wright and Dunham (1972; p. I-858) calculate that for Mississippi delta sediments $2.8 \times 10^{5}$ dynes $/ \mathrm{cm}^{2}$ wave pressure $(600 \mathrm{lbs}$ per square foot) give "stress levels which closely approach failure." Although the applicability of this single number to Mediterranean pelagic sediments is suspect, it does suggest that wave pressure at sites CR and WMR might be sufficient to cause liquefaction while wave pressure at sites EMR and CMR remained too low.

The movement of sediment downslope following liquefaction ("liquefied flow"; Lowe, 1976) is a debris flow within which sediment moves along innumerable shear planes within the body of the material, as opposed to sliding along a few individual shear planes (a "landslide") or following irregular paths in response to fluid turbulence (a "Turbidity current"; Hampton. 1972). Sediments deposited from a debris flow are characterized by extremely poor size-sorting (Middleton and Hampton. 1973). In order to create the graded homogenite bed observed, additional turbulence and additional water must be added to the flow; the debris flow must be transformed into a turbidity current. This can be done by turbulent mixing across the upper interface, mixing into the flow of water trapped beneath the flow, and mixing by flow separation at the head of the flow (Middleton and Hampton. 1973). There is no theory or observation of natural flow to suggest how far a debris flow must move before it becomes a turbidity current. However, the beginning of this transition was observed in a flume only $6 \mathrm{~m}(20 \mathrm{ft})$ long (Hampton. 1972), so 50 to $100 \mathrm{~m}$ of relief is probably sufficient to transform a debris flow into a turbidity current.

Turbidity currents flowing various directions, converging in the basin, combined with sediment suspended by oscillatory currents, would create a seething turbulent mass of suspended sediment over the basin floors. During the weeks following the passage of the tsunami, this would gradually settle out, forming a single graded layer like the observed homogenite.

\section{Possible Objections to the Tsunami Hypothesis}

Why is there no tephra associated with the homogenite? After all, Minoan civilization was devastated by ash falls; the tephra on eastern Crete is several metres thick; and Santorini ash has been recorded in deep-sea cores. However, ash from the 3,500 yr B.P. eruption has been found only in the southeastern corner of the Mediterranean (Fig. 9), presumably because of a northwest wind during the eruption (Watkins and others, 1978; Keller and others, 1978).

Why have none of the previous expeditions in the eastern Mediterranean or in other tsunami-prone areas recorded sediments similar to our homogenite? First, all of our homogenite-bearing cores were recovered from the floor of flat-bottomed depressions a few kilometres across. An unusual tectonic regime is required to produce the depressions in which the-sediment ponded and the high-angle slopes from which it fell. Second, sediment in the tideless, barren abyssal Mediterranean is seldom disturbed by currents or bioturbation and can remain precariously perched on high-angle slopes until set in motion by a catastrophic event. Third, one requires a chronostratigraphic tool capable of recognizing the instantaneous nature of the event. In a uniform pelagic core with only micropaleontologic dating, one might miss this lithology. Among the multicolored marls, oozes, tephras, and sapropels of the Mediterranean cores, it cries out for explanation. Finally, without a large number of cores from a limited area, precisely located with respect to well-mapped physiographic features, it would have been impossible to even conceive such a precise time-space relationship. 
A re-examination of the vast suite of eastern Mediterranean piston cores (starting perhaps with the "giant mud flows" of Stanley and Knight, 1979) with this hypothesis in mind might yeild other examples of "homogenite."

\section{SUMMARY AND CONCLUSIONS}

An unusual sedimentary unit has been observed by nearbottom seismic-reflection profiling and piston coring. A mechanism for its emplacement was sought to explain the following observations:

1. The unit is an extremely uniform gray marl, much thicker (as much as $7.7 \mathrm{~m}$ ) than most strata found in the Mediterranean where changing climatic conditions have caused closely spaced changes in lithology at previous core locations.

2. Grain size decreases regularly from base to top of the unit.

3. The unit is found only in basins, not on slopes or plateaus. Within each basin, the homogenite is flat-lying and terminates abruptly against the steep basin walls.

4. The constituents of homogenite are mineralogically and paleontologically similar to those of the plateau cores.

5. The volume of homogenite in each basin is proportional to the area of steep slope within its "watershed."

6. Gravity cores from basin walls typically have an erosional(?) hiatus under 10 to $20 \mathrm{~cm}$ of recent pelagic sediments.

7. The homogenite occupies the same stratigraphic position in all cores. The $\mathrm{S} 1$ sapropel (date $8,000 \mathrm{yr}$ B.P.) is overlain by normal. pelagic sediment, which is overlain by homogenite, which is overlain by normal pelagic sediment. The ratio of the thickness of the overlying pelagic marl to the underlying pelagic marl is approximately $1: 1$.

8. Two sites west of Crete contained the acoustic transparent layer diagnostic of homogenite. However, the transparent layer was absent at two other sites with similar bathymetry located south and east of Crete.

Observations 2 and 3 imply that the homogenite was emplaced by a gravity-controlled process, but the lack of any layering and the unusual thickness distinguish this unit from the other graded-bed turbidites found in the same cores. Observations 4, 5, and 6 imply that the source of the homogenite was the local basin walls rather than a distant source. Observation 7 implies that homogenite was deposited nearly instantaneously, simultaneously in all basins, and that this event happened between 4400 and $3100 \mathrm{yr}$ B.P.

One of the side benefits of working in the Mediterranean is the long span of civilization in this region, such that events in the 2000 to 1000 B.C. time range are within the historic and archaeological record. We explored this record, looking for a natural event capable: of initiating sediment transport in widely spearated areas, and especially capable of explaining observation 8 . We believe we have found such an event in the tsunami which followed the collapse of: the caldera of the volcano of Santorini during the catastrophic; eruption of $3500 \mathrm{yr}$ B.P. Because of refraction caused by bathyme-. try and because the caldera collapsed in its southwest corner, at disproportionate amount of the energy from the tsunami was directed toward those two sites where homogenite was found.

We suggest two mechanisms by which passage of a tsunami carı initiate sediment transport: erosional scour by oscillatory near. bottom currents, and spontaneous liquefaction. of sediment on a slope subject to cyclic pressure pluses. Even though the calculations of the strength of these mecharisms are fraught with approximations, it does seem that both mechanisms were strong enough to move sediment at the western two homogenite-bearing sites, while neither could move sediment at the eastern two sites. The maximum tsunami-induced near-bottom current at the homogenite-bearing sites probably exceeded $19 \mathrm{~cm} / \mathrm{sec}$, whereas that at the homogenitefree sites was less than $6 \mathrm{~cm} / \mathrm{sec}$. For comparison, calcareous muddy sediment in a flume is eroded under a current of $15 \mathrm{~cm} / \mathrm{sec}$. The estimated magnitude of the pressure pulse at the homogenitebearing sites was greater than $3.5 \times 10^{5}$ dynes $/ \mathrm{cm}^{2}$, that at the homogenite-free sites was less than $0.9 \times 10^{5}$ dynes $/ \mathrm{cm}^{2}$. For comparison, in shal'ow water under storm waves, spontaneous liquefaction occurs at approximately $2.8 \times 10^{5}$ dynes $/ \mathrm{cm}^{2}$.

\section{ACKNOWLEDGMENTS}

We gratefully achnowledge the hard work and long hours of the scientific parties and crews of $\mathrm{R} / \mathrm{V}$ Melville and $\mathrm{R} / \mathrm{V}$ Eastward during their 1978 Mediterranean cruises. Many people contributed to the ideas in this paper and/or reviewed drafts of the manuscript; particularly G. Blechschmidt, K. O. Emery, D. L. Inman, R. Kidd, P. Lonsdale, C. McClennen, F. McCoy, W.B.F. Ryan, F. N. Spiess, D. J. Stanley, S. Ward, and E. L. Winterer. The manuscript and illustrations were prepared swiftly and skillfully by R. Hagen and $J$. Griffith. This work was supported by the National Science Foundation through Grant No. OCE 77-20047 to the Marine Physical Laboratory and to Lamont-Doherty Geological Observatory.

\section{REFERENCES CITED}

Baird, A., 1883, the great tidal wave: Nature, v. 28 , p. 626-627.

Blechschmidt, G.., Cita, M.B., Mazzei, R., and Salvatorini, G., 1981, Stratigraphy of the Western Mediterranean Ridge and Southern Calabrian Ridge, Ionian Basin, Eastern Mediterranean: Marine Micropaleontology (in press).

Boutelle, C., 1884, Water waves from Krakatoa: Science, v. 3, p. 777.

Cita, M. B., Broglia, C., Malinverno, A., Spezzibottani, G., Tomadin, L., and Violanti, D., 1981, Pelagic sedimentation in the Southern Calabrian Ridge and Western Mediterranean Ridge, Eastern Mediterranean: Marine Micropaleontology (in press).

Comninakis, P. E., and Fapazachos, B. C., 1972, Seismicity of the Eastern Mediterranean Ridge: Geological Society of America Bulletin, v. 83, p. 1093-1102.

Dalrymple, R. W., 1979, Wave-induced liquefaction; a modern example from the Bay of Fundy: Sedimentology, v. 26, p. 835-844.

Einsele, G., Overbeck, R., Schwartz, H. U., and Unsold, G., 1974, Mass physical properties, sliding and erodibility of experimentally deposited and differently consolidated clayey muds: Sedimentology, v. 21, p. 339-372.

Hampton, M. A., 1972, The role of subaqueous debris flow in generating turbidity currents: Jourral of Sedimentary Petrology, v. 42, p. 775-793.

Hedervari, P., 1976, Some comparisons between Santorini and Krakatoa Volcanoes, in International Congress on Thermal Waters, Geothermal Energy and Volcanism in the Mediterranean Area, Athens, p. 63-77.

Heezen, B., and Ewing, M., 1952, Turbidity currents and submarine slumps and the 1929 Grand Eanks earthquake: American Journal of Science, v. 250, p. $849-873$.

Henkel, D. J., 1970, The role of waves in causing submarine landslides: Geotechnique, v. 20 , p. 75-80.

Hsï, K., Montadert, L., and others, 1978, Initial reports of the Deep Sea 
Drilling Project; Volume 42: Washington, D.C., U.S. Government Printing Office.

Keller, G. H., and Lambert, D. N., 1973, Geotechnical properties of submarine sediments, Mediterranean Sea, in Stanley, D. J., ed., The Mediterranean Sea; a natural sedimentation laboratory: Stroudsburg, Pennsylvania, Dowden, Hutchinson and Ross, p. 401-415.

Keller, T., Ryan, W.B.F., Ninkovitch, D., and Altherr, R., 1978, Explosive volcanic activity in the Mediterranean over the last 200,000 years as recorded in deep-sea sediments: Geological Society of America Bulletin, v. 89, p. $591-604$.

Kerr, R. A., 1980, A new kind of storm beneath the sea: Science, v. 208, p. 484-486.

Kidd, R. B., Cita, M. B., and Ryan, W.B.F., 1978, Stratigraphy of Eastern Mediterranean sapropel sequences recovered during DSDP 42A and the paleoenvironmental significance, in Hsü, K. J., and others, eds., Initial reports of the Deep Sea Drilling Project, Volume 42, part I: Washington, D.C., U.S. Government Printing Office, p. 421-443.

Kinsman, B., 1965, Wind waves, their generation and propagation on the ocean surface: Englewood Cliffs, New Jersey, Prentice-Hall.

Komolos, G., Hedervari, G., and Meszanos, S., 1978, A brief note on the tectonic earthquakes related to the activity of Santorini from antiquity to the present, in Doumas, C., ed., Thera and the Aegean world, 2nd International Congress on the Volcano of Thera, Proceedings, p. 277283.

Lonsdale, P., and Southard, J. B., 1974, Experimental erosion of North Pacific red clay: Marine Geology, v. 17, M51-M60.

Lowe, D., 1976, Subaqueous liquified and fluidized sediment flows and their deposits: Sedimentology, v. 23, p. 285-308.

Marinos, G., and Melidonis, N., 1971, On the strength of seaquakes (tsunamis) during the prehistoric eruptions of Santorine: International Congress on the Volcano of Thera 1; Proceedings Acta Greek Archeological Service, p. 277-283.

Marshall, N., 1978, Large storm induced sediment slump reopens an unknown Scripps submarine canyon tributary, in Stanley, D. J., and Kelling, G., ed., Sedimentation in submarine canyons, fans and trenches: Stroudsburg, Pennsylvania, Dowden, Hutchinson and Ross, p. 73-84.

Meszaros, S., 1978, Some words on the Minoan tsunami of Santorini, in Doumas, C., ed., Thera and the Aegean world: 2nd International Congress on the Volcano of Thera, Proceedings, p. 257-261.

Middleton, G. V., and Hampton, M. A., 1973, Sediment gravity flows: Mechanics of flow and deposition, in Turbidites and Deep Water Sedimentation, Society of Economic Paleontologists and Mineralogists, Pacific Section, Short Notes.

Mitchell, R. J., Tsui, K. K., and Sangrey, D. A., 1972, Failure of submarine slopes under wave action: Proceedings 13, Coastal Engineers Conference, p. 1515-1541.

Munk, W. H., 1947, Increase in the period of waves travelling over larger distances with special application to tsunamis, swell and seismic waves: Transactions of the American Geophysical Union, v. 28, no 2.

Papazachos, B. C., and Comninakis, P. E., 1971, Geophysical and tectonic features in the Aegean Arc: Journal of Geophysical Research, v. 76, p.
8517-8533.

Partheniades, E., 1965, Erosion and deposition of cohesive soils: Journal of the Hydraulics Division, American Society of Civil Engineers HY1, p. 105-139.

Ryan, W.B.F., Hsü, K. J., and others, 1973, Initial reports of the Deep Sea Drilling Project, Volume 13: Washington, D.C., U.S. Government Printing Office.

Schubel, J. R., Hayes, M. O., and Pritchard, D. W., 1971, The estuarine environment: Estuaries and Estuarine Sedimentation, Short Course Notes, 30-31 Oct., 1971, Wye Institute, American Geological Institute.

Seed, H. B., 1968, Landslides during earthquakes due to Liquification: Journal Soil Mechanics \& Foundations Division, American Society of Civil Engineers, v. 94, SM5, p. 1053-1122.

Seed, H. B., and Idriss, I. M., 1971, Simplified procedures for evaluating liquifaction potential: Journal of Soil Mechanic Foundations Division, American Society of Civil Engineers, v. 97, p. 1249-1273.

Southard, J. B., Young, R. A., and Hollister, C. D., 1971, Experimental Erosion of fine abyssal sediment: Journal of Geophysical Research, v. 76, p. 5903-5909.

Spiess, F. N., and Tyce, R. C., 1973, Marine physical laboratory deep tow instrumentation system: SIO Reference 73-4, p. 37.

Stanley, D. J., and Knight, R. J., 1979, "Giant" mudflow deposits in submarine trenches, Hellenic basins and slopes in Eastern Mediterranean [abs.]: American Association of Petroleum Geologists Bulletin, v. 63, p. 532-533.

Task Committee on Erosion of Cohesive Sediments, Committee on Sedimentation, 1968, Erosion of cohesive sediments: Jour. of the Hydraulics Division, Proceedings American Society of Civil Engineers, HY4, p. 1017-1049.

Ward, S., 1980, Relationships of tsunami generation and an earthquake source: Journal of Physics of the Earth, v. 28, p. 441-474.

Watkins, N. D., Sparks, R.S.J., Sigurdsson, H., Huang, T. C., Federman, A., Carey, S., and Ninkovitch, D., 1978, Volume and extent of the Minoan tephra from Santorini Volcano: New evidence from deep sea sediment cores: Nature, v. 271, p. 122-126.

Wiegel, R. L., 1964, Oceanographical engineering: Englewood Cliffs, New Jersey, Prentice-Hall.

Wright, S. C., and Dunham, R. S., 1972, Bottom stability under wave induced laoding: Offshore Technology Conference Proceedings (Houston, Texas), 1, p. 853-862.

Yokoyama, I., 1978, The tsunami caused by the prehistoric eruption of Thera, in Doumas, C., ed., Thera and the Aegean world: 2nd International Congress on the Volcano of Thera, Proceedings, p. 277-283.

Manuscript Received by the Society March 2, 1981

ReVised ManusCript ReCEIVEd APril 29, 1981

MANUSCRIPT ACCEPTED May 1, 1981

CONTRIBUTION OF THE SCRIPPS INSTITUTION OF

Oceanography, New Series 


\section{Geological Society of America Bulletin}

\section{Tsunami-induced sediment transport in the abyssal Mediterranean Sea}

KIM A. KASTENS and MARIA B. CITA

Geological Society of America Bulletin 1981;92, no. 11;845-857 doi: 10.1130/0016-7606(1981)92<845:TSTITA>2.0.CO;2

\section{Email alerting services}

Subscribe

Permission request click www.gsapubs.org/cgi/alerts to receive free e-mail alerts when new articles cite this article

click www.gsapubs.org/subscriptions/ to subscribe to Geological Society of America Bulletin

click http://www.geosociety.org/pubs/copyrt.htm\#gsa to contact GSA

Copyright not claimed on content prepared wholly by U.S. government employees within scope of their employment. Individual scientists are hereby granted permission, without fees or further requests to GSA, to use a single figure, a single table, and/or a brief paragraph of text in subsequent works and to make unlimited copies of items in GSA's journals for noncommercial use in classrooms to further education and science. This file may not be posted to any Web site, but authors may post the abstracts only of their articles on their own or their organization's Web site providing the posting includes a reference to the article's full citation. GSA provides this and other forums for the presentation of diverse opinions and positions by scientists worldwide, regardless of their race, citizenship, gender, religion, or political viewpoint. Opinions presented in this publication do not reflect official positions of the Society.

\section{Notes}

